\title{
International legal treaty as a basis for scientific cooperation in the Arctic regions
}

\author{
$O$ Maksimova*, and A Armashova \\ Moscow University for the Humanities 5, Yunosti St., Moscow, 111395, Russia
}

\begin{abstract}
The paper analyzes international treaties related to the activities of states in the Arctic regions. These treaties constitute the legal basis for scientific cooperation. Due to the threat of climate change and global warming, the preservation of the Arctic ecosystem is becoming one of the urgent tasks for global scientific community. Russia, with its vast Arctic territories, can play a key role in joining the efforts of scientists from different countries. In the modern world, international cooperation is impossible without the established system of international legal treaties. The main instrument of international law for cooperation in the Arctic is the 1982 UN Convention on the Law Of the Sea. The success of scientific events in the Arctic depends on the results of the activities of the Arctic Council and on the effectiveness of activities, including research during the implementation of the Strategy for the Development of the Arctic Zone of the Russian Federation.
\end{abstract}

\section{Introduction}

Russia is a groundbreaker and has long been a leader in the field of polar research. National scientific research in the Arctic began in the $18^{\text {th }}$ century, when the Great Northern Expedition (1733-1743) of Vitus Bering was organized [1].

During the Soviet period, there was qualitative breakthrough in the development of the Arctic. During this period regular scientific research began to be carried out and reliable knowledge was obtained about this inaccessible region of the Earth.

It is important to note that by the middle of the $20^{\text {th }}$ century, international customs had developed in the Arctic, which regulated the development of this territory and the procedure for scientific research was established in Russian legislation.

Since 1982, a new stage in the development of the legal regime in the Arctic has begun. It is associated with the adoption of the UN Convention on the Law of the Sea. This document established a universal legal regime for maritime spaces, including the basic principles of the implementation of human activities in the Arctic maritime spaces. The Russian Federation confirmed this international treaty on February 6, 1997.

\section{Results}

The 1982 Convention on the Law of the Sea has significantly expanded the range of subjects of international law that may have scientific interests in the
Arctic and the Arctic Ocean. Any state has the right to take part in scientific research of maritime spaces (for example, on the basis of Articles 238 and 254 of the Convention).

Nowadays in addition to the Arctic states, international organizations are actively involved in scientific research in the Arctic. For example, the Arctic Reference Observation Network, the International Arctic Science Committee (as an organization specially created in 1990 to enable scientists from all over the world to work together regardless of nationality), University of the Arctic, Forum of Arctic Research Operators, International Network for Ground Research and Monitoring in the Arctic, World Meteorological Organization, International Council for the Exploration of the Sea, Pacific Arctic Group, Arctic Council, Northern Forum, etc.

For the first time in the history, all states received an undeniable right to conduct marine scientific research, regardless of their geographical location (Article 238 "The right to conduct marine scientific research"). Moreover, the Convention established general principles for the conduct of marine scientific research. The important principle is that they are conducted exclusively for peaceful purposes. It is necessary to take into account that "marine scientific research activities do not create a legal basis for any claims on any part of the marine environment or its resources" (Article 241 "Nonrecognition of marine scientific research as a legal basis for claims"). This provision is a significant limitation and radically changed the situation in the Arctic region.

The Convention has a special section 2 of part XIII devoted to international cooperation. According to the Convention, "states and competent international

*Corresponding author: omaksimova@yandex.ru 
organizations cooperate by bilateral and multilateral agreements in the creation of favorable conditions for marine scientific research in the marine environment and in the combination of the efforts of scientists in the study of the essence of phenomena and processes occurring in the marine environment and the relationship between them (Article 243 "Creation of favorable conditions")".

The important rule is enshrined in Article 246 "Marine scientific research in the exclusive economic zone and the continental shelf". Paragraph 3 of this article establishes that "the coastal states, under normal circumstances, give their consent to the implementation of marine scientific research projects by other states or competent international organizations in their exclusive economic zone or on their continental shelf in accordance with this Convention exclusively for peaceful purposes and to enhance scientific knowledge about the marine environment for the benefit of all mankind. To this end, coastal states shall establish the rules and procedures in order to ensure that there is no undue delay or refusal of such consent."

"One of the important issues in the field of the use of marine spaces of marine resources for Russia is the legal regulation of the Northern Sea Route, which mainly runs through the seas of the Arctic Ocean, in the Arctic zone, and is a route passing through the historical sea space of Russia" [2, 94]. It is necessary to note that for the regulation of the water area of the Arctic Ocean and its seas, the Convention provides the section 8 "Icecovered areas".

There are a large number of international treaties in the world related to the Arctic (today there are more than a hundred). However there is still no general international treaty on the Arctic or any special rules, international legislative acts on the compliance with the environmental safety measures [3]. Therefore, the above mentioned 1982 UN Convention on the Law of the Sea remains the most important document.

The various aspects of the legal regime in the Arctic are regulated by a number of international regional agreements. These include: Arctic Environment Protection Strategy 1991, Kirkenes Declaration 1993, Nuuk Declaration on Environment and Development in the Arctic 1993, Troms $\varnothing$ Declaration 1993, Declaration on the Establishment of the Arctic Council 1996, Ilulissat Declaration of five states coastal to the Arctic Ocean 2008, Kiruna Declaration 2013, Iqaluit Declaration 2015 and others.

In addition to these documents, which are important for the entire Arctic region, a number of bilateral agreements between countries are distinguished, such as the Treaty between the Russian Federation and the Kingdom of Norway on the delimitation of maritime spaces and cooperation in the Barents Sea and the Arctic Ocean in 2011 and many other similar agreements.

Eight Arctic governments signed the Agreement on the Expansion of International Arctic Scientific Cooperation on May 11, 2017 at a meeting organized in the framework of the Arctic Council in Fairbanks, Alaska. This agreement entered into force on May 23, 2018 [4]. The purpose of the Agreement was to expand cooperation in scientific activities in order to increase efficiency and effectiveness in the development of scientific knowledge about the Arctic. The agreement facilitates the access of scientists from Arctic governments to the Arctic territories that are defined by each government, including the entry and exit of people, equipment and materials, access to research infrastructure, facilities and data. The agreement also encourages the parties to promote education, career development, training opportunities and activities related to traditional and local knowledge.

However, this Agreement is essentially a framework document, which implies the achievement of individual agreements within the framework of scientific cooperation in the Arctic if necessary. At the same time, the achieved special agreements should not contradict the norms of international law, as well as the laws, bylaws and procedures of the coastal states.

At the same time, the Agreement, encouraging the member states to make "maximum efforts" to facilitate the entry and exit of people with all the equipment necessary for research, does not imply the obligatory introduction of special documents which allow free border crossing. Article 15 of the Agreement on the resolution of any dispute through direct negotiations is also considered imperfect, since it does not offer a clear solution to the problem if the parties involved in conflict can not come to a compromise during the negotiations.

The Agreement covers the territories designated by the member states of the Arctic Council themselves. At the same time, it is emphasized that the mention of these territories does not mean the recognition of maritime rights or the delimitation of borders between states, which, in turn, does not lead to the resolution of territorial claims in this region.

Summing up the study of this Agreement, the following conclusions can be drawn. Firstly, this agreement testifies to the intensification of the authority of the Arctic Council, under the auspices of which it was prepared, since, despite geopolitical contradictions, it managed to join the efforts of interested states. Secondly, the Agreement brought together not only the member states of the Council, but also all interested countries, which is important for the development of Arctic science. Thirdly, we observe that there is a gradual movement towards the unification of the Arctic region. This indicates the possibility of the transformation of the Arctic region into a demilitarized and exclusively used for peaceful purposes territory by the analogy with the Antarctic Treaty of 1959.

Article 1 "Terms and definitions" of the above mentioned Agreement of May 11, 2017 defines scientific activity as: "the efforts to improve understanding of the Arctic through scientific research, monitoring and assessment. Such activities may include, but are not limited to, the following activities: planning and implementation of research projects and programs, expeditions, observations, monitoring initiatives, surveys, modeling and assessments; staff training; planning, organizing and conducting scientific seminars, symposia, conferences, workshops and meetings; collection, processing, analysis and exchange of scientific data, ideas, results, methods, experience, as well as traditional and local knowledge; development of 
sampling methodologies and protocols; preparation of publications; as well as the development, implementation and use of logistics support for research activities and research infrastructure".

This Agreement provides a fairly impressive list of scientific activities. However, not all of these activities are actively developing. International scientific expeditions seem to be a more complicated type of cooperation that requires serious organizational and material investments.

The study of international treaties and agreements on Arctic issues allows concluding that the implementation of international cooperation in the Arctic in general and scientific cooperation in particular, is associated with a system of international treaties, which present a multilevel hierarchical system.

1. The upper level, represented by the 1982 Convention on the Law of the Sea, defines the belonging of the Arctic Ocean to certain countries and opens up the possibility for non-Arctic countries to conduct various activities in open neutral waters. On the one hand, the inaccessible areas of the subpolar part of the ocean do not contribute to efficient economic activities. On the other hand, it is of undoubted interest for scientific research and environmental monitoring.

2. The middle level is represented by the most important document regulating scientific activities in the Arctic. This is an Agreement signed in 2017 by the governments of 8 Arctic states in order to intensify international Arctic scientific cooperation. The purpose of this document is "to intensify cooperation in the field of scientific activities in order to increase the effectiveness and efficiency of the development of scientific knowledge about the Arctic". However, the main achievement of the Agreement is the opening of access to research areas.

3. The lower, practical level is represented by direct agreements between states, regional governments, international organizations, as well as scientific organizations, which define the Arctic territories as territories for scientific research, or the subject of these scientific studies is the issues related to the Arctic.

This existing system of agreements provides the opportunity for scientific organizations from any country in the world to be involved in scientific cooperation, and even become the initiator of joint scientific projects. Scientific cooperation in the Arctic also face the same problems that are typical of cooperation in other areas in this region: "international cooperation in the Arctic is characterized by some uncertainty, approbation of conflicting principles and a lack of informed decisions on interaction with foreign partners" [5, 42].

The main directions of scientific research and problematic issues can be determined on the basis of documents and materials that are provided by participants in scientific events in the Arctic. Thus, from September 2019 to September 2020, the biggest-ever in the history Arctic expedition Mosaic was organized. The main purpose of which was to get a fundamental understanding of the Arctic as the epicenter of global warming and its impact on climate change. The scientists from 17 countries participated in the project, including Russia, Germany, France, USA and China. The research results were delivered to 80 research institutes. The mission led to unprecedented measurements of what happens in the dark Arctic months to the atmosphere, ocean and ecosystem and sea ice.

While the biggest part of this data remains to be analyzed, early results indicate that the atmosphere of unexplored wilderness with temperature layers is so high that the air at the top of the ship was sometimes $5^{\circ} \mathrm{C}$ warmer than the one closest to the ice. In the ocean, the researchers have found a flourishing ecosystem in dark waters that they believe will be relatively calm.

Scientists are confident that the Arctic ice is disappearing. The shrinking thickness of ice is accelerating global warming. As glaciers in Greenland and other Arctic glaciers lose ice, they are contributing to sea level rise, potentially exposing millions of people to flooding. Nearly all of the dramatic, high-profile impacts of climate change, from alarming coastal erosion to intense and frequent fires, are already happening in the Arctic at a rapid pace.

These expeditions will be included in climate models that will help scientists understand how life in the Arctic will change as it warms and how quickly the rest of the Earth heats up [6].

The most popular and successful type of international scientific cooperation in the Arctic is to plan, organize and conduct scientific seminars, symposia and conferences.

An illustrative and successful example of an international scientific conference on the problems of the Arctic is the Northern Forum on Sustainable Development, which was held in Yakutsk from the $24^{\text {th }}$ to the $28^{\text {th }}$ September, 2019. The representatives of eight circumpolar states (Russia, Canada, USA, Iceland, Finland, Norway, Sweden, Denmark) and the countries of Northeast Asia (China, South Korea and Japan) attended this event, as well as a delegation of the Ministry for the Development of the Far East and the Arctic of the Russian Federation, Far East agencies for attraction of investments and export support, Nenets and Khanty-Mansi Autonomous District, Kamchatka and Khabarovsk Territories.

The Northern Forum on Sustainable Development was held for the first time in Yakutsk in 2019. A total of 111 guests came to the forum, including 51 foreign guests from 14 countries including the circumpolar ones (Iceland, Canada, USA, Finland, Norway, Russia) and the countries of Northeast Asia (China, South Korea and Japan), and also from Germany, France, Great Britain, Lithuania, Switzerland.

The main organizers of the Northern Forum on Sustainable Development were the International NonGovernmental Organization of the Northern Regions "Northern Forum", the Government of the Republic of Sakha (Yakutia), North-Eastern Federal University named after M.K. Ammosov.

The co-organizers of the event were: Project Office for the Development of the Arctic (Moscow), Russian International Affairs Council (Moscow), St. Petersburg State University (St. Petersburg), Surgut State Pedagogical University, Siberian Federal University (Krasnoyarsk). 
The following international organizations took part in the organization of the Northern Forum on Sustainable Development in 2019: International Arctic Science Committee (IASC), Arctic University, Institute of Circumpolar Reindeer Husbandry of Arctic University, International Reindeer Center, Association of "Reindeer Herders of the World", Education Committee of the International Association of permafrost studies, Association of Mayors of the World Winter Cities (Sapporo, Japan). The scientific program of this conference was rich in various events [7]. Scientists from Russia and China discussed cooperation in the Arctic at a round table at the Northern Forum on Sustainable Development and bilateral cooperation in the Arctic. The most interesting discussion at the round table was the discussion of the issues of institutional cooperation and the legal framework for future partnership".

The International UNESCO Chair of the NorthEastern Federal University presented an international project on digitalization of the linguistic and cultural heritage of the indigenous peoples of the North and the Arctic on September 27, at the project session of the Northern Forum on Sustainable Development.

During this event many scientific topics and developments related to the problems of the Arctic were covered. The Forum brought together an authoritative representation of scientists from academic institutions and universities. Thus, the Northern Forum on Sustainable Development, held in 2019, served as a platform to establish international scientific ties between Russian scientists and their foreign colleagues. Thus, the scientists from the University of Laval (Quebec, Canada), University of Northern British Columbia (Prince George, Canada), Oceanological University of China (Qingdao, China), Shanghai Institute of International Studies (Shanghai, China), Arctic University of Norway (Troms $\varnothing$, Norway), Arctic Center of the University of Lapland (Rovaniemi, Finland) attended this forum. Moreover, it is necessary to note that "Russia is open to international cooperation in the Arctic; however, on the other hand, the national security of its northern borders is the most important priority of its policy" [8, 281].

Let us mention another major event as an example of international cooperation in the format of a scientific forum. The $5^{\text {th }}$ International Arctic Forum "The Arctic Territory of Dialogue" was on April 9-10, 2019 in St. Petersburg. More than 3,600 people from 52 states, including China, Norway, Finland, Sweden, USA, Denmark, Iceland, Canada and Japan attended this event.

The participants discussed the issues of the Northern Sea Route (NSR), environmental preservation, and rational use of natural resources, interaction in security provision, sustainable development of indigenous peoples of the North and the development of international cooperation. The heads of state in their speeches emphasized the significant role of the Arctic Council in the solution of these issues.

The proposal announced at the forum to create a scientific and educational center in the Arctic, which will ensure the development of fundamental science and solve practical problems of the development of the Arctic, also seems promising. The joint development of the educational standard for this center by the countries participating in the Arctic Council will allow training highly qualified Arctic specialists for international projects [9].

\section{Discussion}

When we talk about the achievements of Russian scientific expeditions that managed to reach different territories including the Pacific coast and begin the development of northeastern Russia, it is necessary to mention the contribution of the indigenous peoples of Siberia. Thus, the Yakuts and other peoples of Eastern Siberia in the $18^{\text {th }}-19^{\text {th }}$ centuries rendered invaluable assistance in the transportation of goods for expeditions on Russian Arctic development, providing their horses for transportation. The details about this contribution of the Siberian peoples are described in the work of M.M. Fedorov "The legal status of the peoples of Eastern Siberia (the $17^{\text {th }}$-early $19^{\text {th }}$ century)" $[10]$.

In our opinion, the Russian model of scientific cooperation in the Arctic should take into account the priorities of state policy in the Arctic, the benefits of direct interaction with scientists from other countries, the possibilities of international organizations in which Russia and its constituent entities participate. The priority tasks of the "Strategy for the development of the Arctic zone of the Russian Federation and provision of national security for the period up to 2035" are defined the tasks of social development [11]. Consequently, the priority topics of scientific research in the Arctic should primarily include the issues of socio-economic development.

International scientific cooperation should be based on the principle of priority of the interests of the Arctic states. A timely decision is the creation of the Scientific Arctic Council under the Government of the Russian Federation, which determines the priorities and topics of scientific research in the region, including those carried out in cooperation with international scientists. It is necessary to coordinate the activities of more than 500 organizations in 50 regions conducting scientific research on Arctic topics [12].

The problem of the contradictory nature of the norms of international agreements and the norms of national legislation is a problem of legal science. Today Russia is developing modern legal regulation for a hard-to-reach territory, such as the Arctic. A problematic issue is the question of the definition of rights and their guarantees for legal entities in the Arctic zone. According to Article 2 of the International Covenant on Economic, Social and Cultural Rights "the rights reflected in this Covenant will be exercised without any discrimination, such as race, color, sex, language, religion, political or other beliefs, national or social origin, property status, birth or other circumstance". Thus, the provision of additional guarantees and expansion of the scope of rights to individual subjects of law may be in conflict with an international treaty. 
Some proposals and solutions developed by the scientific community on the problems of legal regulation in the Arctic can be found in the final documents of major scientific conferences [13].

\section{Conclusions}

1) With the adoption of the 1982 convention, the scientific activity of scientists from different countries has increased. Especially the activity on the study of the Arctic by scientists from nonArctic countries has increased, for example, China, Japan and South Korea.

2) There are certain scientific traditions and customs in the scientific study of the Arctic, but they are not sufficiently taken into account by modern international law, which often provokes the contradictions between participants in international relations.

3) The regulatory framework for international cooperation in the Arctic is not sufficiently developed and analyzed by national legal scholars and requires a more thorough study in order to develop an optimal model for the development of the Russian Arctic, including the development and implementation of priority areas of scientific research.

4) The clear priorities in the definition of the goals of scientific research and reduction of secondary topics will allow Russian scientific organizations to enter into contractual relations in the field of scientific cooperation in the Arctic, make them more effective, give an opportunity to abandon topics which are not useful or contradictory in terms of the national interests of Russia.

5) Scientific and scientific-practical conferences are one of the instruments for the development of contractual relations in the field of international scientific cooperation in the Arctic. In particular, it is the Northern Forum on Sustainable Development being held in Yakutsk. It should be assumed that the role of conferences and other formats of scientific interaction are not to define or approve the agenda of international scientific research, but to create an atmosphere of trust between scientists, assess the capabilities and style of work, develop a common scientific discourse and conceptual apparatus.

6) There is no doubt that the content of reports and scientific discussion should become the primary material for the formation of proposals on priority topics of scientific research, which should be evaluated and implemented at the state level.

\section{References}

1. Pasetskiy V.M. Russian discoveries in the Arctic: in 2 parts. (St. Petersburg: Admiralty, 2000)

2. Maksimova O.D. Global Dialogue on Sustainable Development Goals: Legal
Dimension (to the $75^{\text {th }}$ Anniversary of the $U N$ ), p. 94-98 (Moscow, 2020)

3. The final public resolution on the socioeconomic development of the Arctic zone of the Russian Federation for 2019, IX International Forum "Arctic: Present and Future. (SPb., 2019) Retrieved from: http://www.forumarctic.com/upload/conf2019/r esolution/Rezolution-2019.pdf

4. Agreement on the expansion of international Arctic scientific cooperation in 2017 Retrieved from: https://docs.cntd.ru/document/456059402

5. Chumakov D.S. Bulletin of Moscow University, 25. International relations and world politics. 2 , 41-61, (2011)

6. MOSAiC Multidisciplinary drifting Observatory for the Study of Arctic Climate Science Plan Retrieved from: MOSAiC Expedition (mosaicexpedition.org)

7. Final report for 2019. Northern Forum on Sustainable Development, September 24-28, Retrieved from:: https://nsdf.ru/report/

8. Nikolaev A.N., Maksimova D.D., Kugunurov V.V. University - Intellectual, Innovative and Spiritual Platform for Sustainable Development of the Macroregion. (Yakutsk, 2021)

9. Results of the International Arctic Forum "The Arctic - Territory of Dialogue" Retrieved from: https://roscongress.org/upload/medialibrary/f14/ itogi-v-mezhdunarodnogo-arkticheskogoforuma_rus.pdf

10. Fedorov M.M. Legal status of the peoples of Eastern Siberia (XVII - early XIX century). (Yakutsk, 1978).

11. Decree of the President of the Russian Federation of October 26, 2 No. 645 "On the Strategy for the Development of the Arctic Zone of the Russian Federation and Ensuring National Security for the Period until 2035" (2020) Retrieved from: https://www.garant.ru/products/ipo/prime/doc / $74710556 /$

12. Trutnev Y. Meeting on the organization of research and development in the Arctic zone Retrieved from: http://government.ru/news/40437/

13. Final public resolution on the socio-economic development of the Arctic zone of the Russian Federation for 2020, XI International Forum "Arctic: Present and Future" Retrieved from: http://www.forumarctic.com/conf2020/ 